\title{
VOLATILE COMPOUNDS OF NATURAL UNCLARIFIED STRAWBERRY JUICE
}

\section{Zamorska}

\section{Uman National University of Horticulture}

\begin{tabular}{l}
$\quad$ Key words: \\
Strawberry \\
Juice \\
Volatiles compounds \\
Sort \\
Aroma \\
\hline
\end{tabular}

Article history:

Received 09.01.2018

Received in revised form

29.01.2018

Accepted 14.02.2018

Corresponding author:

I. Zamorska

E-mail:

zil197608@gmail.com

\begin{abstract}
Strawberry juice is a valuable product of processed strawberry; its odor is formed under the effect of fresh berry flavor, however technological processes of heating and cooling may have a considerable impact on the content and composition of volatile compounds.

The purpose of the work was to study the content and composition of volatile compounds in natural unclarified strawberry juice. The content and composition of volatile compounds in natural unclarified strawberry juice, made of cultivars Dukat, Honey and Polka, were determined using the method of highly efficient liquid chromatography. To identify a share of each component, odor activity value (OAV) was determined with the help of division of substance concentration by its threshold concentration.

It was established that total number of aromatic compounds in natural unclarified strawberry juice was $17.51 \mathrm{mg} / \mathrm{kg}$. Ethers, aldehydes, acids, lactones, furanic derivatives and terpines were found in the composition of volatile compounds. Acids and furanones make a considerable share from the total volatile compounds among juice aromatic compounds, $60.1 \%$ and $28.9 \%$ respectively.

The calculation of volatile compound activity showed that furanic derivatives dominated among them: 2.4-dioxy-2.5-dimethyl-3(2H)-furane-3-on and 2.5-dimethyl-4-methoxy-3(2H)furanone (mesifurane), which added sweet, caramel aroma.

High activity was recorded in $\gamma$-decalactone, which added fruit sweet flavor, and in linalool, which added sweet flower aroma. Ethylbutanoate appeared to be very active among others, represented in juice odor, and typical for fresh grass flavor. 2-methylbutanoic acid and hexanoic acid, which added sour-sweet flavor, were also active compounds.
\end{abstract}

DOI: $10.24263 / 2225-2924-2018-24-1-27$

\section{ЛЕТКІ СПОЛУКИ СОКУ СУНИЧНОГО НАТУРАЛЬНОГО НЕОСВІТЛЕНОГО}

\section{І.Л. Заморська \\ Уманський національний університет садівництвва}

Цінним продуктом переробки з ягід суниці є суничний сік, аромат якого формується під впливом аромату свіжих ягід, проте технологічні операції 
підігрівання й охолодження можуть істотно вплинути на вміст $і$ склад летких сполук.

У статті досліджено вміст і склад летких сполук соку суничного натурального неосвітленого. Сік суничний натуральний неосвітлений із ягід суничі суміші сортів Дукат, Хоней та Полка досліджено на вміст і склад летких сполук методом високоефективної рідинної хроматографії. Для встановлення вкладу кожного компонента визначали активність аромату (OAV) шляхом ділення концентрачії речовини на ї̈ порогову конщентрацію.

Встановлено, що загальна сума ароматичних сполук у сокові суничному натуральному неосвітленому складала 17,51 мг/кг. У складі летких сполук виявлено ефіри, альдегіди, кислоти, лактони, фуранові похідні й терпени. Вагому частку серед ароматичних сполук соків складали кислоти - 60,1\% та фуранони - 28,9\% від загальної суми летких сполук. На частку ефірів припадає 3,9\%, натомість вміст альдегідів не перевищив значення 1,3\% від загальної суми летких сполук соку суничного.

Розрахунок активності летких сполук показав, щзо серед них домінують фуранові похідні: 2,4-диокси-2,5-диметил-3(2H)-фуран-3-он $і$ 2,5-диметил-4метокси-3(2Н)-фуранон (мезифуран), які надають солодких, карамельних тонів.

Високу активність виявляють $\gamma$-декалактон, що відповідає за фруктові солодкі тони та ліналоол - солодкі квіткові. Серед ефірів, що представлені в ароматі соку, значну активність виявляє етилбутаноат, який характерний для свіжих трав'янистих нот. Активними сполуками також є 2-метилмасляна кислота та капронова кислота, що надають аромату кисло-солодкого відтінку.

Ключові слова: суниця, сік, леткі сполуки, сорт, аромат.

Постановка проблеми. Суниця - одна 3 найбільш поширених і цінних ягідних культур в Україні та світі завдяки раннім строкам достигання, високій урожайності, прекрасним смаковим властивостям і гармонійному аромату ягід. Компонентами аромату ягід суниці $є$ більш ніж 360 сполук, що являють собою ефіри, альдегіди, кетони, спирти, лактони, терпенові сполуки, фуранони [1-3]. Основна частина припадає на ефіри, що за різними даними складають $25-90 \%$ від загальної суми сполук, альдегіди і фуранони, частка яких становить до $50 \%[1 ; 2]$. Вони надають аромату суниці фруктових і квіткових нот, зелених, солодких або ж карамельних $[4 ; 5]$.

Цінним продуктом переробки 3 ягід суниці є суничний сік, що займає значну частку в асортименті соків 3 плодів і ягід. Очевидно, що аромат соків із суниці формується під впливом аромату свіжих ягід, проте технологічна схема виробництва соку натурального неосвітленого із суниці включає операції підігрівання до $85-90^{\circ} \mathrm{C}$ та охолодження до температури $30-35^{\circ} \mathrm{C}$ 3 подальшим сепаруванням, що може істотно вплинути на збереженість аромату.

Відомо, що внаслідок високотемпературної обробки, карамелізації цукрів та реакції Майяра консерви із суниці набувають вареного, спаленого і карамельного смаків [5-7]. Так, аромат джемів із суниці формується під впливом 
кислот, спиртів і ефірів [8], що мають як природне походження, так і можуть виникати в результаті теплової обробки. Стерилізування ж суничного пюре із соком зумовлює значну втрату квіткових ароматів 3 одночасним утворенням гераніолу та ваніліну [9]. Аромат компотів із суниці формується під впливом фуранонів $(15,5-23,5 \%)$ та ароматичних кислот $(48,4-76,1 \%)$, що надають солодких карамельних і кисло-солодких тонів [10]. Проте в науковій літературі недостатньо інформації про кількісний та якісний склад летких сполук соку суничного натурального неосвітленого.

Мета статті: дослідження вмісту і складу летких сполук соку суничного натурального неосвітленого.

Матеріали і методи. Дослідження проводили протягом 2012-2013 pp. 3 ягодами суниці сортів Дукат, Хоней та Полка в умовах лабораторії кафедри технології зберігання і переробки плодів та овочів Уманського національного університету садівництва та у випробувальному центрі з контролю якості харчової продукції Національного інституту винограду і вина «Магарач» (Україна).

Суницю збирали у технічній стадії стиглості, сортували за якістю, очищували і мили. 3 підготовлених ягід суміші сортів суниці виготовляли сік суничний натуральний неосвітлений згідно з зчинною технологічною інструкцією [11] та фасували у скляну тару місткістю $250 \mathrm{~cm}^{3}$. Зберігали сік протягом шести місяців за температури $20^{\circ} \mathrm{C}$.

Для визначення летких сполук у соках використовували хроматограф Agilent Technologies 6890 з мас-спектрометричним детектором 5973 і хроматографічною капілярною колонкою DB-5 внутрішній діаметр 0,25 мм і довжиною 30 м. Для ідентифікації компонентів використовували бібліотеку масспектрів NIST05 i WILEY 2007 із загальною кількістю спектрів більш 470000 в поєднанні з програмами для ідентифікації AMDIS і NIST.

Для кількісних розрахунків використовували метод внутрішнього стандарту. Розрахунок вмісту компонентів проводили за формулою:

$$
C=\mathrm{K}_{1} \cdot \mathrm{K}_{2},
$$

де $C$ - вміст летких компонентів мг/кг;

$$
\mathrm{K}_{1}=\frac{\Pi_{1}}{\Pi_{2}}
$$

де $\Pi_{1}$ — площа піку досліджуваної речовини; $\Pi_{2}$ — площа піку стандарту;

$$
\mathrm{K}_{2}=\frac{50}{\mathrm{M}},
$$

де 50 - маса внутрішнього стандарту (мкг), що введений у зразок; М наважка зразка (грам).

Для встановлення вкладу кожного компонента визначали активність аромату (OAV) шляхом ділення концентрації речовини на ії порогову концентрацію [12].

Статистичний аналіз виконували за допомогою програми StatSoft STATISTICA 6.1.478 Russian, Enterprise Single User (2007). 
Результати і обговорення. Дослідження вмісту і складу летких сполук соку суничного натурального неосвітленого показали, що загальна сума ароматичних сполук у сокові складала 17,51 мг/кг (табл. 1). У складі летких сполук соків із суниці виявлено ефіри, альдегіди, кислоти, лактони, фуранові похідні і терпени. Вагому частку серед ароматичних сполук соків складали кислоти - 60,1\% та фуранони - 28,9\% від загальної суми летких сполук соку. Аналогічні дані отримані при дослідженні вмісту і складу летких сполук компотів з суниці [10].

\section{Таблиия 1. Леткі сполуки соку суничного натурального неосвітленого, мг/кг}

\begin{tabular}{|c|c|}
\hline Ароматичні сполуки & Вміст, мг/кг \\
\hline 1 & 2 \\
\hline \multicolumn{2}{|c|}{ Ефіри } \\
\hline Етилбутаноат & 0,21 \\
\hline 2-метилбутилацетат & 0,02 \\
\hline Метилкапронат & 0,03 \\
\hline Етилкапронат & 0,03 \\
\hline 3-метилбутилбутаноат & 0,04 \\
\hline Гексилформіат & 0,11 \\
\hline Ізоамілбутаноат & 0,24 \\
\hline Сума ефірів & 0,68 \\
\hline \multicolumn{2}{|c|}{ Альдегіди } \\
\hline Бензальдегід & 0,09 \\
\hline Транс-2-гексен-1-ол & 0,06 \\
\hline Фурфурол & 0,08 \\
\hline Сума альдегідів & 0,23 \\
\hline \multicolumn{2}{|c|}{ Ароматичні сполуки } \\
\hline 2Н-пиран-2,6(3Н)-дион & 0,29 \\
\hline Сума ароматичних сполук & 0,29 \\
\hline \multicolumn{2}{|c|}{ Кислоти } \\
\hline 2-метилмасляна кислота & 0,27 \\
\hline Каприлова кислота & 0,10 \\
\hline Нонанова кислота & 0,08 \\
\hline Капронова кислота & 1,08 \\
\hline Міристинова кислота & 0,19 \\
\hline Пальмітоолеїнова кислота & 0,14 \\
\hline Пальмітинова кислота & 1,66 \\
\hline 2-етилкапронова кислота & 0,84 \\
\hline Транс корична кислота & 2,80 \\
\hline Лауринова кислота & 0,08 \\
\hline Лінолева кислота & 2,91 \\
\hline Стеаринова кислота & 0,14 \\
\hline Цис-корична кислота & 0,23 \\
\hline Сума кислот & 10,52 \\
\hline \multicolumn{2}{|c|}{ Лактони } \\
\hline$\gamma$-декалактон & 0,15 \\
\hline$\gamma$-додекалактон & 0,08 \\
\hline Сума лактонів & 0,23 \\
\hline
\end{tabular}




\begin{tabular}{|c|c|}
\hline & Продовження табл. 1 \\
\hline 1 & 2 \\
\hline \multicolumn{2}{|l|}{ Фуранові похідні } \\
\hline 2,4-діокси-2,5-диметил-3(2Н)-фуран-3-он & 0,22 \\
\hline 2,5-диметил-4-метокси-3(2Н)-фуранон (мезифуран) & 3,67 \\
\hline 2,5-диметил-4-окси-3(2Н)-фуранон & 1,18 \\
\hline Сума фуранових похідних & 5,07 \\
\hline \multicolumn{2}{|l|}{ Терпени } \\
\hline Ліналоол & 0,07 \\
\hline$\alpha$-терпінеол & 0,05 \\
\hline Бісабололоксид А & 0,15 \\
\hline Бісабололоксид Б & 0,08 \\
\hline Неролідол & 0,14 \\
\hline Сума терпенів & 0,49 \\
\hline Загальна сума ароматичних сполук & 17,51 \\
\hline $\mathrm{HIP}_{05}$ & 0,06 \\
\hline
\end{tabular}

На частку ефірів припадає 3,9\%, натомість вміст альдегідів не перевищив значення $1,3 \%$ від загальної суми летких сполук соку суничного.

Серед загальної кількості летких сполук вагому частку займали 2,5-диметил-4-метокси-3(2Н)-фуранон (мезифуран) (21\% від загальної суми летких сполук соку), лінолева кислота (16,6\%), транскорична кислота $(16,0 \%)$, пальмітинова кислота $(9,5 \%), 2,5$-диметил-4-окси-3(2Н)-фуранон $(6,7 \%)$, капронова кислота $(6,2 \%), 2$-етилкапронова кислота $(4,8 \%)$. Варто зауважити, що серед летких сполук соку натурального неосвітленого із суниці виявлено фурфурол, який був ідентифікований раніше в інших продуктах переробки 3 ягід суниці, що свідчить про ознаки неферментативного потемніння продукту.

Серед ефірів у соку із суниці ідентифіковано етилбутаноат у кількості $1,2 \%$ від загального вмісту летких сполук та ізоамілбутаноат - $1,4 \%$. Частка кожного з інших ефірів, що виявлені в сокові, знаходилася на рівні $0,1-0,6 \%$. Вміст альдегідів не перевищував 0,5\%. Також виявлено 2Н-піран-2,6(3H)-діон, частка якого складає $1,7 \%$ від загальної суми летких сполук та свідчить про проходження реакції Майяра.

Терпенові сполуки соку суничного натурального неосвітленого представлені ліналоолом (0,4\% від загальної суми летких сполук), $\alpha$-терпінеолом $(0,3 \%)$, що надають аромату соку пряних нот, і бісабололоксидом А $(0,9 \%)$, бісабололоксидом Б $(0,5 \%)$, неролідолом $(0,8 \%)$, що відповідають за солодкі квіткові тони.

Розрахунок активності летких сполук соку суничного натурального неосвітленого показав (табл. 2), що домінують фуранові похідні: 2,4-діокси-2,5-диметил-3(2Н)-фуран-3-он і 2,5-диметил-4-метокси-3(2Н)-фуранон (мезифуран), що надають солодких, карамельних тонів.

Таблиия 2. Активність летких сполук аромату соку суничного натурального неосвітленого (OAV)

\begin{tabular}{|c|c|c|}
\hline Ароматичні сполуки & $\begin{array}{c}\text { Порогова } \\
\text { концентрація, мг/кг }\end{array}$ & $\begin{array}{c}\text { Активність летких сполук } \\
\text { аромату (OAV) }\end{array}$ \\
\hline 1 & 2 & 3 \\
\hline Етилбутаноат & 0,018 & 3,5 \\
\hline
\end{tabular}




\begin{tabular}{|c|c|c|}
\hline \multicolumn{3}{|c|}{ Продовження табл. 2} \\
\hline 1 & 2 & 3 \\
\hline Етилкротонат & $\mathrm{HД}^{\mathrm{I}}$ & - \\
\hline 2-метилбутилацетат & НД & - \\
\hline Етилкапронат & НД & - \\
\hline Метилкапронат & НД & - \\
\hline 3-метилбутилбутаноат & НД & - \\
\hline Гексилформіат & НД & - \\
\hline Ізоамілбутаноат & НД & - \\
\hline Бензальдегід & 0,35 & 0,26 \\
\hline Транс-2-гексен-1-ол & НД & - \\
\hline Фурфурол & 3 & 0,03 \\
\hline 2Н-піран-2,6(3Н)-діон & НД & - \\
\hline 2-метилмасляна кислота & 0,25 & 1,1 \\
\hline Каприлова кислота & 0,910 & 0,1 \\
\hline Нонанова кислота & 3 & 0,03 \\
\hline Капронова кислота & 1,0 & 1,08 \\
\hline 2-етилкапронова кислота & НД & - \\
\hline Транс корична кислота & НД & - \\
\hline Лауринова кислота & 10 & 0,008 \\
\hline Лінолева кислота & НД & - \\
\hline Стеаринова кислота & 20 & 0,007 \\
\hline Цис-корична кислота & НД & - \\
\hline Міристинова кислота & 10 & 0,019 \\
\hline Пальмітоолеїнова кислота & НД & - \\
\hline Пальмітинова кислота & НД & - \\
\hline$\gamma$-декалактон & 0,01 & 15,0 \\
\hline$\gamma$-додекалактон & НД & - \\
\hline $\begin{array}{c}\text { 2,4-діокси-2,5-диметил-3(2Н)-фуран- } \\
\text { 3-он } \\
\end{array}$ & $0,00004^{2}$ & 5500,0 \\
\hline $\begin{array}{c}2,5 \text {-диметил-4-метокси-3(2Н)-фуранон } \\
\text { (мезифуран) }\end{array}$ & $0,00003^{2}$ & 122333,3 \\
\hline 2,5-диметил-3(2Н)-фуранон & НД & - \\
\hline Ліналоол & 0,006 & 11,7 \\
\hline$\alpha$-терпінеол & 0,330 & 0,15 \\
\hline бісабололоксид А & НД & - \\
\hline бісабололоксид Б & НД & - \\
\hline Неролідол & НД & - \\
\hline
\end{tabular}

${ }^{1}$ НД - немає даних. Порогові концентрації речовин (у воді) отримані з бази ароматів Leffingwell \& Associates.

${ }^{2}$ Siegmund B., Bagdonaite K., Leitner E [13].

Високу активність виявляли $\gamma$ - декалактон, що відповідає за фруктові солодкі тони, та ліналоол - солодкі квіткові. Серед ефірів, що представлені в ароматі соку, значну активність виявляли етилбутаноат, який характерний для свіжих трав'янистих нот. Активними сполуками також були 2-метилмасляна кислота та капронова кислота, що надавали аромату кисло-солодкого відтінку.

\section{Висновки}

Аромат соку суничного натурального неосвітленого представлений складною сумішшю сполук, серед яких кількісно переважають кислоти - 60,1\% та 
фуранони - 28,9\% від загальної суми летких сполук. Проте за активністю аромату домінують фуранові похідні, що відповідають за солодкі карамельні тони, $\gamma$-декалактон - фруктові солодкі тони та ліналоол - солодкі квіткові. Серед ефірів значну активність виявляє етилбутаноат, який характерний для свіжих трав'янистих нот, а також 2-метилмасляна та капронова кислоти, що надають аромату кисло-солодкого відтінку.

\section{Лiтeparypa}

1. Larsen M. Odour thresholds of some important aroma compounds in strawberries / M. Larsen, L. Poll //Zeitschrift für Lebensmittel-Untersuchung und Forschung. — 1992. T. 195. - \# 2. - P. 120-123. DOI: 10.1007/BF01201770.

2. Larsen $M$. Evaluation of the aroma composition of some strawberry (Fragaria ananassa Duch) cultivars by use of odour threshold values / M. Larsen, L. Poll, C.E. Olsen // Zeitschrift für Lebensmittel-Untersuchung und Forschung. - 1992. - T. 195. — \# 6. - P. 536-539. DOI: $10.1007 / \mathrm{BF} 01204558$.

3. Forney C.F. The composition of strawberry aroma is influenced by cultivar, maturity, and storage / C.F. Forney, W. Kalt, M.A. Jordan // HortScience. — 2000.-T. 35. — \# 6. P. 1022-1026 [Електронний ресурс]. — Режим доступу: http://hortsci.ashspublications.org/content/35/6/1022.full.pdf.

4. Vandendriessche T. et al. High-Throughput Flavor Evaluation of Strawberry Cultivars: Focus on Aroma Development during Ripening // IV International Conference Postharvest Unlimited 2011 945. - 2011. - P. 227-232.

5. Pérez A.G. Furanones in strawberries: evolution during ripening and postharvest shelf life / A.G. Pérez, R. Olías, C. Sanz and J.M. Olías // Journal of agricultural and food chemistry. 1996. — T. 44. — \# 11. — P. 3620-3624. DOI: 10.1021/jf960099m.

6. Sloan J.L. Heat-induced compounds in strawberries / J. L. Sloan, D. D. Bills, L.M. Libbey // Journal of Agricultural and Food Chemistry. — 1969. — T. 17. — \# 6. - P. 1370 - 1372. DOI: 10.1021/jf60166a020.

7. Avasoo M. Evaluation of thermal processing technologies for strawberry jam. / M. Avasoo, L. Johansson. - 2011 [Електронний pecypc]. - Режим доступу: http://ukkpfhd.livsmedelsakademin.se/sites/default/files/media/evaluation_of_thermal_processing_tec hnologies_for_strawberry_jam.final_.pdf.

8. Barren $D$. The volatile constituents of strawberry jam/ D. Barren, P. X. Etiévant// Zeitschrift für Lebensmittel-Untersuchung und Forschung. - 1990. - T. 191. — \# 4-5. P. 279-285. DOI: 10.1007/BF01202426.

9. Lambert $Y$. Changes in aromatic volatile composition of strawberry after high pressure treatment / Y. Lambert, G. Demazeau, A. Largeteau, J. M. Bouvier //Food Chemistry. — 1999. T. 67. —\# 1. - P. 7-16. DOI:10.1016/S0308-8146(99)00084-9.

10. Заморська І.Л. Вміст і склад летких компонентів суничних компотів //Вісник Харківського національного аграрного університету. Серія «Рослинництво, селекція і насінництво, плодоовочівництво і зберігання» / Редкол.: Л.М. Пузік (гол. ред.) та ін. Харків, 2015. — № 1. - С. 171-181.

11. Сборник технологических инструкций по производству консервов. Т. 2. Ч.1. Консервы фруктовые. - Москва : Консервплодоовощхоз, 1992. — 275 с.

12. Kim Y.H. Quantitative Analysis of Fragrance and Odorants Released from Fresh and Decaying Strawberries / Y.H. Kim, K.H. Kim, J.E. Szulejko, D. Parker //Sensors. - 2013. T. 13. — \# 6. - P. 7939-7978. DOI:10.3390/s130607939.

13. Siegmund B. Furaneol and mesifuran in strawberries - an analytical challenge / B. Siegmund, K. Bagdonaite, E. Leitner // Expression of Multidisciplinary Flavour Science; Blank, I.; Wüst, M. - 2008. - P. 537-540. 